\title{
EFEK PELATIHAN LARI AKSELERASI DAN PELATIHAN LARI INTERVAL DI PANTAI BERPASIR DALAM MENINGKATKAN KEMAMPUAN ANAEROBIK, POWER OTOT TUNGKAI DAN KECEPATAN LARI 100 METER PADA SISWA KELAS X SMA NEGERI 1 SUELA LOMBOK TIMUR TAHUN PELAJARAN 2018/2019
}

\section{Lilik Evitamala ${ }^{1}$, I Nyoman Adiputra ${ }^{2}$, Luh Putu Ratna Sundari ${ }^{3}$, Luh Made Indah Sri} Handari Adiputra ${ }^{4}$, I Putu Adiartha Griadhi ${ }^{5}$, Susy Purnawati6

${ }^{1}$ Program Magister Fisiologi Keolahragaan Fakultas Kedokteran, Universitas Udayana, Denpasar $2,3,4,5,6$

Departemen Faal, Fakultas Kedokteran, Universitas Udayana e-mail : lilikevitamala18@gmail.com

\begin{abstract}
ABSTRAK
Lari 100 meter dikenal juga dengan lari jarak pendek dimana pelari harus menempuh jarak 100 meter dengan waktu yang sesingkat-singkatnya. Menjadi seorang pelari 100 meter yang baik sangat membutuhkan kemampuan anaerobik serta membutuhkan power otot tungkai. Tujuan dari penelitian ini yaitu untuk mengetahui peningktan kemampuan anaerobik, power otot tungkai serta kecepatan lari 100 meter dari efek pelatihan lari akselerasi dan pelatihan lari interval di pantai berpasir pada siswa kelas X SMA Negeri 1 Suela Lombok Timur. Telah dilakukan penelitian experimental Pre-Post Test Control Group Disgn pada 30 orang siswa yang berumur 16-17 tahun yang memiliki tingkat kebugaran fisik sedang atau cukup. Sampel dikelompokkan menjadi dua dengan menggunakan teknik alokasi acak sederhana. Kelompok I diberikan pelatihan lari akselerasi di pantai berpasir dan Kelompok II diberikan pelatihan lari interval di pantai berpasir. Rerata kemampuan anaerobik, power otot tungkai dan kecepatan lari 100 meter pada masing masing kelompok, memiliki $\mathrm{p}<0,05$. Artinya pada tiap-tiap kelompok, terjadi perubahan peningkatan secara siknifikan. Kesimpulan penelitian ini adalah pelatihan lari akselerasi dan pelatihan lari interval di pantai berpasir sama sama dapat meningkatkan kemampuan anaerobik, power otot tungkai dan kecepatan lari 100 meter.
\end{abstract}

Kata kunci : Lari akselerasi, lari interval, kemampuan anaerobik, power otot tungkai, lari $100 \mathrm{~m}$.

\section{THE EFFECT OF TRAINING OF ACCELERATION RUNNING AND \\ INTERVAL RUNNING AT SANDY BEACH IN IMPROVING THE CAPABILITY OF ANAEROBIC, THE POWER OF LIMB MUSCLES AND 100 METERS' RUNNING SPEED ON TENTH GRADE STUDENTS AT PUBLIC HIGH SCHOOL (SMA NEGERI) 1 SUELA IN EAST LOMBOK, SCHOOL YEAR OF 2018/2019}

\section{ABSTRAK}

100 meters' run is a short distance that someone has to run with repulsion as fast as possible up to distance 100 meters'. Become a good runner must have anaerobic capability, power of limb 
muscles. This research aims to find out the improvement of anaerobic capability, power of limb muscles and 100 meters' running speed from the effect of training of acceleration running and interval running at sandy beach on tenth grade students at SMA Negeri 1 Suela in East Lombok. An experimental study of Pre-Post Test Control Group Design had been conducted on 30 students aged between 16-17 years old who had physical fitness level of medium or moderate. Samples were divided into two groups by using simple random allocation technique. Group I was given the training of acceleration running at sandy beach and group II was given the training of interval running at sandy beach. The average of anaerobic capability, power of limb muscles and 100 meters' running speed on each group, has $\mathrm{p}<0.05$. It means that on each group, there is a meaningful and significant improvement change after training. It can be concluded that the training of acceleration running and interval running at sandy beach equally improving anaerobic capability, the power of limb muscles and 100 meters' running speed.

Key words: Acceleration running, interval running, anaerobic capability, power of limb muscles, 100 meters' running.

\section{PENDAHULUAN}

Pelari 100 meter harus mempunyai beberapa asfek antara lain asfek mental, fisik, teknik dan taktik, asfek fisiklah yang sangat penting perannya dari pada aspek asfek lainya. "Komponen biomotorik yang dominan dalam berlari 100 meter di pengaruhi oleh daya tahan, kekuatan, kelentukan ,daya ledak, kecepatan, keseimbangan waktu reaksi, dan koordinasi". 1 dari komponen tersebut yang sangat penting mendapat perhatian yaitu komponen daya tahan anaerobik, power otot tungkai dan kecepatan.

Kemampuan anaerobik yaitu kemampuan kardiovaskular untuk berfungsi secara baik dan optimal. "Power otot tungkai yaitu kemampuan untuk menghadapi beban, dengan usaha yang diperintahkan dalam waktu yang singkat". 3 Kecepatan lari 100 meter termasuk dalam lari jarak pendek yang menggunakan kemampuan secara maksimal untuk menempuh waktu sesingkat-singkatnya sejauh 100 meter.

Metode pelatiahan yang digunakan pada penelitian ini yaitu menggunakan metode pelatihan 'lari akselerasi dan pelatihan lari interval' di pantai berpasir dalam meningkatkan kecepatan lari karena tekstur pasir yang lembut dan cukup dalam saat diinjak sehingga memberi efek beban yang lebih pada saat berlari.
"Menurut Fox, et al pelatihan akselerasi yaitu suatu bentuk pelatihan yang meningkatkan kecepatan secara perlahanperlahan yaitu berlari dari jogging terus meningkat sampai lari secepat-cepatnya". ${ }^{4}$ Sedangkan "pelatihan interval yaitu pemberian beban pelatihan pada tubuh dalam waktu singkat tetapi teratur dan berulangulang, diselingi dengan interval. Contohnya dengan jalan atau dengan jogging". 5 Pada ke dua pelatihan kondisi fisik yang diperlukan adalah kemapuan anaerobik, power otot tungkai, kecepatan, dan kekuatan.

\section{METODE}

Penelitian ini dengan menggunakan rancangan "Exsperimental Randomized Pretest-Postes Control Grup Design". sampel dalam penelitian ini sebanyak 30 orang siswa yang di bagi menjadi dua kelompok dengan tiap-tiap kelompok 15 orang siswa. Kelompok I mendapatkan pelatian lari akselerasi dan Kelompok II mendapatkan pelatihan lari interval di pantai berpasir.

Penelitian ini dilaksanakan di SMA Negeri 1 Suela Lombok Timur dan di pantai Ketapang. Pelaksanaan pelatihan selama 6 minggu terhitung dari awal bulan Januari sampai dengan pertengahan bulan Maret 2019. Pelatihan dilakukan pada sore hari dimulai pukul 16.00-17.30 WITA. 


\section{HASIL PENELITIAN}

\section{Karakteristik Subjek Penelitian}

Tabel 1

Karakteristik Sampel

\begin{tabular}{|c|c|c|c|}
\hline Karakteristik & & $\begin{array}{l}\text { kelompok I } \\
\text { Pelatihan lari } \\
\text { akselerasi }\end{array}$ & $\begin{array}{c}\text { Kelompok II } \\
\text { Pelatihan lari } \\
\text { interval }\end{array}$ \\
\hline Subjek & $\mathrm{n}$ & Rerata \pm SB & Rerata \pm SB \\
\hline Umur (th) & 15 & $16,40 \pm 0,51$ & $16,33 \pm 0,48$ \\
\hline Berat Badan (kg) & 15 & $51,06 \pm 3,21$ & $52,06 \pm 4,46$ \\
\hline Tinggi Badan $(\mathrm{cm})$ & 15 & $163 \pm 4,21$ & $161 \pm 5,51$ \\
\hline IMT $\left(\mathrm{kg} / \mathrm{m}^{2}\right)$ & 15 & $19,15 \pm 0,53$ & $19,95 \pm 1,15$ \\
\hline
\end{tabular}

Melihat pada Tabel 1, menunjukkan bahwa pada karakteristik Umur, BB (Berat Badan), TB (Tinggi Badan) dan IMT (Indeks Massa Tubuh) pada subjek tidak berbeda jauh.

\section{Uji Normalitas dan Homogenitas}

"Uji normalitas kemampuan anaerobik, Kelompok I sebelum pelatihan: $\mathrm{p}=0,188$ setelah pelatihan: $\mathrm{p}=160$ dan Kelompok II sebelum pelatihan $p=0,144$, setelah pelatihan: $\mathrm{P}=0,364$. Power otot tungkai Kelompok I sebelum pelatihan: $p=$ 0,941 , setelah pelatihan: $p=0,654$ dan Kelompok II sebelum pelatihan $\mathrm{p}=0,804$, setelah pelatihan: $\mathrm{p}=0,579$. Kecepatan lari 100 meter Kelompok I sebelum pelatihan $\mathrm{p}=0,625$, setelah pelatihan: $\mathrm{p}=0,374$ dan
Kelompok II sebelum pelatihan: $p=0,474$, setelah pelatihan $\mathrm{p}=0,477$. Artinya pada penelitian ini menerangkan bahwa kemampuan anaerobik, power otot tungkai dan kecepatan waktu tempuh lari 100 meter berdistribusi normal sebab nilai $(\mathrm{p}>0,05)$. Kemudian data diuji menggunkan uji parametrik untuk melihat adanya peningkatan ataukan penurunan hasil pada variabel penelitian". Uji normalitas menggunakan saphiro wilk test.

Uji homogenitas kemampuan anaerobik Kelompok I dan Kelompok II sebelum pelatihan $\mathrm{p}=0,794$, setelah pelatihan $\mathrm{p}=0,996$. Power otot tungkai Kelompok I dan Kelompok II sebelum pelatihan $\mathrm{p}=0,420$ setelah pelatihan $\mathrm{p}=$ 0,347 . Kecepatan waktu tempuh lari 100 meter Kelompok I dan Kelompok II sebelum pelatihan $\mathrm{p}=0,408$, setelah pelatihan $\mathrm{p}=0,383$. Artinya data menunjukkan bahwa penelitian pada ke dua kelompok terhadap kemampuan anaerobik, power otot tungkai dan Kecepatan lari 100 meter berdistribusi homogen karena nilai ( $\mathrm{p}$ $>0,05)$ kemudian data dapat diuji menggunakan uji parametrik. "Uji homogenitas menggunakan levens test".

3."Hasil Uji Data Kemampuan Anaerobik, power otot tungkai dan kecepatan lari 100 meter antara Sebelum dan Sesudah Pelatihan Pada Kelompok I dan Kelompok II"

Tabel 2.

Uji t-paired kemampuan anaerobik, power otot tungkai dan kecepatan lari $100 \mathrm{~m}$

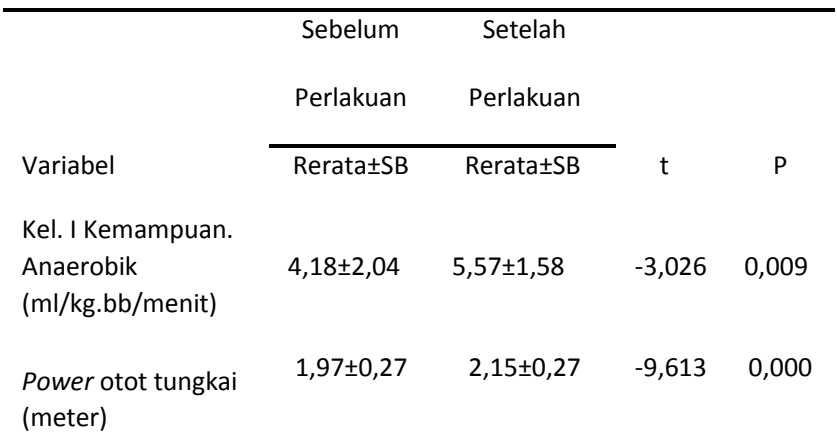




\begin{tabular}{|c|c|c|c|c|c|c|c|c|c|}
\hline Lari $100 \mathrm{M}$ (detik) & $14,96 \pm 1,27$ & $14,68 \pm 0,27$ & 7,241 & 0,000 & & & & & \\
\hline Kel. II kemampuan & $3,79 \pm 1,63$ & $5,30 \pm 1,74$ & 4,389 & 0,001 & $\begin{array}{l}\text { Kel. II power otot } \\
\text { tungkai (meter) }\end{array}$ & $2,15 \pm 0,27$ & $2,11 \pm 0,24$ & 0,347 & 0,731 \\
\hline $\begin{array}{l}\text { anaerobiK } \\
\text { (ml/kg.bb/menit) }\end{array}$ & & & & & $\begin{array}{l}\text { Kel. I lari } 100 \mathrm{M} \\
\text { (detik) }\end{array}$ & $14,96 \pm 1,27$ & $15,11 \pm 1,49$ & $-0,279$ & 0,783 \\
\hline Power otot tungkai & $2,01 \pm 023$ & $2,11 \pm 0,24$ & $-7,000$ & 0,000 & & & & & \\
\hline (meter) & & & & & $\begin{array}{l}\text { Kel. I I lari } 100 \\
\text { M (detik) }\end{array}$ & $14,68 \pm 0,27$ & $15,06 \pm 1,48$ & $-0,769$ & 0,448 \\
\hline Ları 1 & $15,11 \pm 1,49$ & $15,06 \pm 1,48$ & 7,897 & 0,000 & & & & & \\
\hline
\end{tabular}

Melihat Tabel 2, rerata kemampuan anaerobik, power otot tungkai dan kecepatan waktu tempuh lari 100 meter setelah pelatihan pada tiap-tiap Kelompok, mempunyai nilai $\mathrm{p}<0,05$. Artinya bahwa pada tiap-tiap kelompok, terjadi perubahan peningkatan terhadap kemampuan anaerobik, power otot tungkai dan kecepatan waktu tempuh lari 100 meter setelah pelatihan secara signifikan. Oleh sebab itu dapat dismpulkan bahwa ke dua bentuk pelatihan ini, sama-sama dapat memberi efek terhadap meningkatkan kemampuan anaerobik, power otot tungkai dan kecepatan waktu tempuh lari 100 meter.

\section{Uji data kemampuan anaerobik power} otot tungkai dan kecepatan lari $100 \mathrm{M}$. Antar Kelompok I (Akselerasi) dengan Kelompok II (Interval) sebelum pelatihan dan setelah pelatihan"

Tabel 3.

Uji t-independent Kemampuan Anaerobik Power Otot Tungkai dan Kecepatan lari 100 meter"

\begin{tabular}{lllll}
\hline & Sebelum & Setelah & & \\
& Perlakuan & Perlakuan & & \\
& Rariable & t & P
\end{tabular}

Kel.

IKemampuan.

Anaerobik

(ml/kg.bb/menit)

Kel. II

kemampuan

anaerobik

(ml/kg.bb/menit) tungkai (meter)
Kel. I power otot
$4,18 \pm 2,04 \quad 3,79 \pm 1,63 \quad 0,583 \quad 0,565$

$5,57 \pm 1,58$

$5,30 \pm 1,74-0,433$

0,668
Melihat Tabel ke 3, menunjukkan bahwa kemampuan anaerobik, power otot tungkai dan keceptan waktu tempuh pada tiap-tiap kelompok memiliki nilai $\mathrm{p}=0,05$ artinya antara kelompok I dan II setelah diberikan perlakuan tidak berbeda bermakna karena $\mathrm{p}>0,05$.

\section{PEMBAHASAN}

"Efek Pelatihan Lari Akselerasi dan Pelatihan Lari Interval di Pantai Berpasir terhadap Kemampuan Anaerobik"

Pelatihan lari akselerasi merupakan pelatihan lari menggunakan pertambahan kecepatan lari secara gradual atau bertahap, mulai dari pelan-pelan, semakin cepat dan lari secepat-cepatnya dalam jarak 100 meter. Pelatihan ini juga termasuk olahraga yang menggunakan sistem energi anaerobik dalam aktivitasnya ditinjau dari durasi waktu yang di tempuh kurang dari satu menit.

Pelatihan lari interval' merupakan pelatihan lari menggunakan tenaga maksimal yang diselingi dengan jalan dalam jarak 100 meter, misalnya berlari sekencang kencangnya sejauh 100 meter dan kembali dengan jalan sejauh 100 meter. Pelatihan interval ini juga termasuk pelatihan yang meningkatkan kemampuan anaerobik yang ditinjau dari durasi waktu tempuh dalam aktivitasnya kurang dari satu menit. Pelatihan ini menyebabkan kemampuan anaerobik meningkat karena menstimulasi kinerja pada otot dalam intensitas tinggi sehingga meningkatkan kemampuan atau kekuatan serta daya tahan pada otot. "Latihan anaerobik merupakan latihan untuk membangun otot yang lebih kuat. Ketika melakukan latihan anaerobik energi yang tersimpan dalam otot akan digunakan sebagai sumber energi 
cadangan yang digunakan untuk latihan berikutny. ${ }^{7}$

Kerja sistem anaerobik di jelaskan oleh Bompa dalam (Imanudin) sebagai berikut: pada waktu $\mathrm{CP}$ yang tersimpan dengan jumlah terbatas dalam sel otot, energi dapat digunakan oleh sitem ini antara 8-10 detik. Sistem ini merupakan sumber energi utama untuk aktivitas yang sangat singkat atau cepat dan eksplosif. Sistem asam laktat mencegah glikogen yang tersimpan dalam sel otot dan dalam hati, yang lebih dari $\mathrm{CP}$, yang melepaskan energi untuk membentuk kembali ATP yang berasal dari ADP+P. Pemecahan glikogen tanpa $\mathrm{O}^{2}$ akan menghasilkan asam laktat. Pada waktu intensitas kerja atau latihan yang tinggi dilanjutlan untuk priode waktu yang lama, maka sejumlah besar asam laktat terkumpul dalam otot sehingga terjadilah kelelahan yang akhirnya menyebabkan terhentinya aktivitas fisik". 8

Hasil pada penelitian ini diperoleh peningkatan kemampuan anaerobik pada ke dua kelompok, dan didukung oleh penelitian sebelumnya yang dilakukan pada pemain bulu tangkis putra usia 11-13 Tahun PB. Pendowo Semarang yang diberikan pelatihan lari interval pendek 10 minute triangle run menunjukkan adanya peningkatan pada daya tahan anaerobik..$^{\prime \prime}$

\section{"Efek Pelatihan Lari Akselerasi dan Pelatihan Lari Interval di Pantai Berpasir terhadap Power Otot Tungkai"}

Efek 'pelatihan lari akselerasi' dan 'pelatihan lari interval' di pantai berpasir dapat meningkatkan power otot tungkai karena dalam melakukan aktivitas berlari otot-otot yang dominan digunakan adalah otot tungkai secara otomatis kemampuannya akan meningkat akibat pelatihan tersebut. Dan berlari di pantai berpasir karena tekstur pasir yang lembut dan cukup dalam saat diinjak akan bemberikan efek beban yang lebih, power otot tungkai meningkat maka kecepatan dalam berlari juga akan meningkat.
Hasil pada penelitian ini diperoleh peningkatan power otot tungkai pada ke dua kelompok, dan didukung oleh penelitian "Djoko, yang meneliti siswa putra SMP yang mengikuti ekstrakulikuler atletik bahwa hasil penelitiannya mengemukakan pelatihan acceleration sprint lebih baik dibandingkaan sprint training untuk meningkatan kekuatan otot tungkai yang. ."10

Adam juga, menggunakan metode pelatihan lari interval untuk meningkatkan waktu tempuh kecepatan lari 100 meter meter terhadap siswa SMP, bahwa hasil pengamatannya menunjukkan bahwa pencapaian siswa mengenai kecepatan lari selalu bertambah 1 detik dari kecepatan awal yang dicapai. Oleh karena itu latihan interval teratur merupakan bentuk latihan pada otot tungkai kaki sehingga aktivitas fisik dengan berlari dapat memanfaatkan potensi kemampuan tungkai dan tubuh untuk berlari semaksimal mungkin dan mencapai waktu seminimal mungkin."11

\section{"Efek Pelatihan Lari Akselerasi dan Pelatihan Interval di Pantai Berpasir terhadap Kecepatan Lari 100 Meter".}

Dalam sprint atau lari jarak pendek, kemampuan berlari dalam fase percepatan akselerasi 0 sampai dengan 30 meter sangat mempengaruhi dalam kesuksesan mencapai garis akhir atau finish. Hasil pada penelitian ini diperoleh peningkatan kecepatan lari 100 meter pada ke dua kelompok, dan di dukung oleh penelitian sebelumnya yang dilakukan pada siswa SD Negeri 2 Tawing Trenggalek melalui metode pelatihan lari akselerasi bahwa ada peningkatan yang signifikan terhadap kecepatan lari cepat 100 meter. $^{12}$

"Apri, juga meneliti mengenai pengaruh metode lari akselerasi terhadap kecepatan lari pemain sepak bola Putra Wjaya Kota Padang, hasil penelitiannya ini menyimpulkan bahwa latihan acceleration sprint memberikan dampak terhadap kecepatan lari pemain Putra Wijaya Kota Padang secara signifikan". ${ }^{13}$ Jadi pelatihan lari 
akselerasi di pantai berpasir kemungkinan memiliki efek terhadap fase percepatan akselerasi dilihat dari aktivitasnya pada saat berlari setiap kurang lebih 30 meter menambah kecepatan mulai dari jogging dilajutkan lari sedang kemudian lari secepatcepatnya.

Pelatihan lari interval di pantai berpasir berefek terhadap speed maintenance atau fase pemeliharaan kecepatan pada 60 meter sampai dengan 100 meter, dapat dilihat dari bentuk latihannya dari start sampai dengan garis finish menggunakan kecepatan maksimal. Pada penelitian Nahak, tentang pelatihan lari interval di pasir pantai dan di lapangan dapat meningkatkan waktu tempuh lari 100 meter. $^{14}$

Kemampuan anaerobik merupakan kesiapan dari pada kardiovaskular untuk berfungsi baik dan optimal". ${ }^{2}$ Oleh sebab itu, kemampuan anaerobik yang baik sangat penting dimiliki oleh semua atlet terutama atlet pemain untuk mempertahankan kondisi fisiknya.

Hasil penelitian ini menunjukkan bahwa pelatihan lari akselerasi dan pelatihan lari interval di pantai berpasir sama-sama meningkatkan kemampuan anaerobik, power otot tungkai serta kecepatan lari 100 meter karena beban pelatihan yang tidak berbeda jauh, hal ini dibuktikan dari beban kerja lari akselerasi sebesar 142-168 kali/menit dan pelatihan lari interval $140-162 \mathrm{kali} /$ menit serta pelatihan yang dilakukan sama-sama di pasir, menyebabkan perubahan terhadap kapasitas jantung dan paru-paru, kemampuan otot, VO2maxnya dan lainnya terjadi pada latihan lari akselerasi dan pelatihan lari interval tidak berbeda jauh. Dan pelatihan lari akselerasi kemungkinan berpengaruh pada fase percepatan akselerasi 0-30 meter, dan pelatihan lari interval berpengaruh pada speed maintenance atau pada fase pemeliharaan kecepatan pada jarak 60-100 meter sehingga ke dua pelatihan ini sama-sama memiliki efek baik dalam melewati setiap fase-fase pada lari jarak pendek yang dapat berpengaruh pada keberhasilan menempuh garis finish.

\section{KELEMAHAN PENELITIAN}

Pengukuran kecepatan lari hanya mengukur waktu tempuh dari garis start sampai dengan garis finish, tidak dilakukan pengukuran waktu tempuh pada fase akselerasi yang di mulai dari 0 sampai dengan $30 \mathrm{~m}$, kecepatan maksimum pada jarak 30 sampai 60 $\mathrm{m}$, dan speed maintenance pada jarak $60 \mathrm{~m}$ sampai dengan $100 \mathrm{~m}$. Diharapkan pada penelitian selanjutnya melakukan pengukuran pada setiap fase kecepatan lari jarak pendek, untuk mengetahui berapa detik kemampuan atlet berlari pada setiap fasenya.

\section{SIMPULAN}

1. Pelatihan lari akselerasi di pantai berpasir dapat meningkatkan kemampuan anaerobik, power otot tungkai dan kecepatan lari 100 meter.

2. Pelatihan lari interval di pantai berpasir dapat meningkatkan "kemampuan anaerobik, power otot tungkai dan kecepatan waktu tempuh lari 100 meter.

3. Pelatihan lari akselerasi dan pelatihan lari interval di pantai berpasir samasama meningkatkan kemampuan anaerobik, power otot tungkai dan kecepatan waktu tempuh lari 100 meter.

\section{DAFTAR PUSTAKA}

1. Purba A. 2018. Prosedur Pelaksanaan Tes Kondisi Fisik. Bandung: Bagian Ilmu Faal Dan Olahraga Fakultas Kedokteran UNPAD.

2. Irianto, P. D. 2004. Pedoman praktis berolahraga untuk kebugaran dan kesehatan. Yogyakarta: Andy Ofset.

3. Sajoto, M.2002. Peningkatan dan Pembinaan Kakuatan Kondisi Fisik. Semarang: Effhar dan Dhara Prize.

4. Fox, E.L., Bower, R.W. and Foss, M.L. 1988. The Physiological Basic of 'Physical Education and Athletic. Philadelphia: Saunders College Publishers. 
5. Nala, I.G.N. 2015. Prinsip Kepelatihan Olahraga. Denpasar: UNUD Press.

6. Pocock, S. J. 2008. Chemical Trial, a Pratical Aproach, New York: A Willey Medical Publication.

7. Giriwijoyo,S. 2004. Ilmu Faal Olahraga. Bandung: FPOK-Universitas Pendidikan Indonesia.

8. Imanudin, I. 2008. Ilmu Kepelatihan Olahraga. Bandung: UPI.

9. Handayani, D. 2017. 'Pengaruh Latihan Interval Pendek Dan 10 Minute Triangle Run Terhadap Indeks Kelelahan Pemain Bulu Tangkis usia 11 tahun'.http://lib.unnes.ac.id.ISSN:63014112-31. Diunduh 17 mei 2019.

10. Djoko, P. 2016. "Perbedaan Pengaruh Metode Latihan Acceleration _Sprint dan Sprint_Training Terhadap Prestasi Lompat Jauh ditinjau Dari Power Otot Tungkai Studi Eksperimen pada Siswa Putra SMP Negeri1Ngawi"'.http://eprints.uns.ac.id/i d/eprint/29907 diunduh 17 mei 2019

11. Adam, A. R. 2011. Pemberian Latihan Interval Dalam Meningkatkan Kemampuan Kecepatan Lari 100 Meter terhadap siswa SMP. Journal_Ilara.http://digilib.unm.ac.id/dis k1/7/universitas\%20negeri\%20makasard igilibunmadamabdulr33716.adamk.pdf.3 April 2019.

12. Nahak, B. 2014.Pelatihan Lari Interval $4 x 50$ Meter di Pantai Berpasir Lebih Meningkatkan Kecepatan Lari 100 Meter dari pada Pelatihan Lari Interval di Lapangan Pada Siswa Kelas X SMK $N$ Kakulukmesak NTT. Sport and Fitness Journal. Universitas Udayana. ISSN: 2302-688X.

13. Sukadiyanto. 2011. Pengantar Teori dan Metodologi Melatih Fisik. Bandung: Lubuk Agung.

14. Santun, 2018. 'Peningkatan Hasil Belajar Lari Cepat 100 M Melalui Metode Akselerasi'.Journal.unublitar.ac.id/pendi dikan/index.php/riset_konseptual/article/ view/19. 3 April 2019. 